\title{
PEMBUDIDAYAAN SELEDRI DI PEKARANGAN RUMAH SEBAGAI ALTERNATIF PENURUNAN HIPERTENSI PADA LANSIA
}

\author{
Lasria Simamora ${ }^{1}$, Srilina Br.Pinem ${ }^{2}$, Henni Rista ${ }^{3}$ \\ 1,2,3,4 STIKes Mitra Husada Medan \\ lasriasimamora@gmail.com, srilina46@gmail.com, hennysaputro80@gmail.com
}

\begin{abstract}
Abstrak
Tahun 2020 Hipertensi merupakan penyakit tidak menular yang menjadi salah satu penyebab utama kematian prematur di dunia. Organisasi kesehatan dunia (World Health Organization / WHO) mengestimasikan saat ini prevalensi hipertensi secara global sebesar $22 \%$ dari total penduduk dunia. Salah satu penanganan hipertensi adalah penanganan non-farmakologi yakni dengan memanfaatkan seledri. Seledri mengandung apigenin, flavonoid, vitamin $\mathrm{C}$, apiin, kalsium, dan magnesium untuk mencegah penyempitan pembuluh darah dan menurunkan hipertensi. Kegiatan ini bertujuan untuk meningkatkan pengetahuan masyarakat tentang hipertensi dan penggunaan seledri sebagai alternatif penanganan hipertensi dan pembudidayaannya dengan memanfaatkan pekarangan rumah. Adapun tahapan kegiatanya adalah melakukan pengkajian hipertensi, sosialisasi, demonstrasi/pengajaran (memilih bibit seledri, melakukan pencampuran tanah maupun kompos, melakukan penanaman bibit seledri), pendampingan menanam seledri dengan di pekarangan rumah masyarakat. Hasil dari kegiatan ini adalah masyarakat memahami tentang penyakit hipertensi mulai dari definisi, etiologi, manifestasi klinis, pemeriksaan diagnostik, pencegahan serta pengontrolan tekanan darah pada penderita hipertensi dengan memanfaatkan daun seledri serta terlaksananya budi daya tanaman seledri di pekarangan rumah penduduk di wilayah kerja puskesmas Simalingkar.
\end{abstract}

Kata Kunci : Hipertensi, Seledri, Puskesmas

\section{PENDAHULUAN}

\section{Analisis Situasi}

Penyakit darah tinggi atau hipertensi merupakan suatu gangguan pada pembuluh darah dan jantung yang mengakibatkan suplay oksigen dan nutrisi yang dibawa oleh darah terhambat sampai ke jaringan tubuh.Tekanan darah tinggi yang terus menerus menyebabkan jantung bekerja keras, sehingga mengakibatkan terjadinya kerusakan pembuluh darah jantung, otak, dan mata .

Kriteria hipertensi yang digunakan pada penetapan kasus merujuk pada kriteria diagnosis Joint National Commite (JNC) VII pada tahun 2003, yaitu hasil pengukuran tekanan darah sistolik $\geq 140 \mathrm{mmHg}$ atau tekanan darah diastolik $\geq 90$ mmHg. Kriteria JNC VII 2003 hanya berlaku untuk umur $\geq 18$ tahun, maka prevalensi hipertensi berdasarkan pengukuran tekanan darah dihitung hanya pada penduduk umur $\geq 18$ tahun (Kemenkes RI, 2019).

Berdasarkan data Riskesdas 2018, Prevalensi hipertensi pada umur $\geq 18$ tahun di Indonesia meningkat menjadi 34,1\%, dari Riskesdas 2013 sebesar 25,8\% (Kemenkes RI, 2018). Dari data perpropinsi, Sumatera Utara juga memiliki angka prevalensi hipertensi yang cukup tinggi yaitu sebesar 24,7\% (Sumatera Utara, 2019). Puskesmas Simalingkar merupakan salah satu puskesmas dibawah naungan Dinas Kesehatan kota Medan yang juga turut serta melaksanakan program 
nasional dengan melakukan posbindu PTM. Pada tahun 2016, penyakit hipertensi menempati urutan ke-tiga dari sepuluh penyakit tertinggi di wilayah kerja Puskesmas Simalingkar dengan angka kejadian hipertensi sebanyak 500 orang, angka ini mengalami peningkatan tiap tahun, dan pada tahun 2018 mencapai 1.479 orang.

\section{Peningkatan tekanan darah yang} berlangsung dalam jangka waktu lama (persisten) dapat menimbulkan kerusakan pada ginjal (gagal ginjal), jantung (penyakit jantung koroner) dan otak (menyebabkan stroke) bila tidak dideteksi secara dini dan mendapat pengobatan yang memadai. Hipertensi merupakan salah satu penyakit degeneratif. Dengan bertambahnya usia, denyut jantung maksimum dan fungsi lain jantung juga berangsur menurun. Pada lanjut usia, tekanan darah akan naik secara bertahap, elastisitas otot jantung pada orang berusia 70 tahun menurun sekitar $50 \%$ dibandingkan orang muda berusia 20 tahunan. Penggolongan lansia menurut WHO meliputi: middle age (45-59 tahun), elderly (60-74 tahun), old (75-90 tahun), very old (diatas 90 tahun) (James et al., 2014).

Saat gejala timbul, hipertensi menjadi penyakit yang harus diterapi seumur hidup, pengobatan yang harus dikeluarkan cukup mahal dan membutuhkan waktu yang lama. Selain terapi farmakologi, pengobatan hipertensi juga dapat dilakukan dengan terapi non farmakologi diantaranya dengan memanfaatkan daun seledri. Seledri (Apium graveolens L) merupakan salah satu dari jenis terapi herbal untuk menangani penyakit hipertensi. Seledri memiliki kandungan apigenin yang sangat bermanfaat untuk mencegah penyempitan pembuluh darah dan tekanan darah tinggi. Selain itu, seledri juga mengandung flavonoid, vitamin C, apiin, kalsium, dan magnesium yang dapat membantu menurunkan tekanan darah tinggi (Djojoseputro, 2012). Dimasyarakat sendiri masih banyak yang belum mengetahui tentang kandungan daun seledri, sehingga banyak penderita lebih memilih obatobatan sebagai anti hipertensi, padahal daun seledri sendiri cukup mudah didapatkan dan harga yang relatif terjangkau. Seledri (Apium graveolens L.) dapat tumbuh pada suhu $15-21^{\circ} \mathrm{C}$, sehingga tidak sulit ditemukan di Indonesia (Khomsan, 2010).

Secara khusus, seledri mengandung 3-n-butyl phthalide $(3 \mathrm{nB})$, suatu senyawa yang tidak hanya bertanggung jawab untuk bau yang khas seledri, tetapi juga telah ditemukan untuk menurunkan tekanan darah dengan merelaksasi atau melemaskan otot-otot halus pembuluh darah.Penelitian yang telah dilakukan bahwa setelah makan seperempat pon seledri setiap hari selama 1 minggu,mengamati bahwa tekanan darahnya telah turun dari 158/96 mmHg ke 118/82 mmHg. Selain itu penelitian yang telah dilakukan oleh Oddy menunjukkan bahwa terdapat perbedaan signifikan terhadap tekanan darah sukarelawan sebelum dan sesudah ekstrak etanol seledri. Nilai rata-rata tekanan darah sistole $116,02 \mathrm{mmHg}$ dan tekanan darah diastole 74,79 mmHg, sedangkan setelah minum ekstrak etanol seledri yaitu tekanan darah systole 109,40 $\mathrm{mmHg}$ dan tekanan darah diastole 70,20 mmHg (Madhavi, D., Kagan, D., Rao, V., dan Murray., 2013)

Apigenin dalam seledri berfungsi sebagai beta blocker yang dapat memperlambat detak jantung dan menurunkan kekuatan kontraksi jantung sehingga aliran darah yang terpompa lebih sedikit dan tekanan darah menjadi berkurang. Manitol dan apiin, bersifat diuretik yaitu membantu ginjal mengeluarkan kelebihan cairan dan garam dari dalam tubuh, sehingga berkurangnya cairan dalam darah akan menurunkan tekanan darah (Rahayu Sri, 2017). Penelitian ini didukung oleh Penelitian yang dilakukan oleh Halimah \& Ekwantini, 2014 pada tikus rattus strain wistar dengan hipertensi yang diberi jus seledri (Apium graveolens L.), dimana terjadi penurunan sistolik rata- rata pada tikus rattus strain wistar sebanyak $3 \mathrm{mmHg}(\mathrm{p}=0,000)$ (Harmilah \& Ekwantini, 2014)

Pengabdian yang dilakukan oleh Wijaya, (2019) menyatakan bahwa hasil dari kegiatan yang dilakukan yaitu masyarakat memahami tentang penyakit hipertensi mulai dari definisi, etiologi, manifestasi klinis, pemeriksaan diagnostik, pencegahan serta pengontrolan tekanan darah pada penderita hipertensi dengan memanfaatkan daun seledri serta terlaksananya budi daya tanaman seledri di pekarangan rumah masyarakat desa 
Serumbung Kecamatan Kerkap,Kabupaten Bengkulu Utara.

Tujuan dalam kegiatan ini adalah meningkatkan pengetahuan masyarakat lansia tentang manfaat dan pembudidayaan seledri.

\section{METODE}

Metode yang digunakan adalah 1) Sosialisasi; Tahap sosialisasi mencakup pengenalan seledri yang dapat menjadi salah satu penangan hipertensi non-farmakologi dan sekaligus dapat membantu perekonomian keluarga dengan cara membudidayakan seledri dengan memanfaatkan pekarangan rumah sendiri. 2) Demonstrasi/pengajaran; Tahap pengajaran dilakukan dengan membentuk kelompok kecil sebanyak 3 kelompok yang terdiri dari 3 anggota disetiap kelompoknya dari masyarakat wilayah kerja puskesmas Simalingkar dan kemudian dipilih leader dari kelompok tersebut sebagai penanggungjawab. Tahap pengajaran bertujuan untuk memberikan pemahaman secara teori terhadap masyarakat mitra sehingga masyarakat siap untuk melakukan pembudidayaan seledri dipekarangan rumah. Tahap pengajaran mencakup antara lain memilih bibit seledri, melakukan pencampuran tanah maupun kompos, melakukan penanaman bibit seledri dan juga perawatan seledri sebelum dipanen. 3) Pendampingan; Melakukan pendampingan menanam seledri dengan di pekarangan rumah masyarakat.

\section{HASIL DAN PEMBAHASAN}

\section{Sosialisasi}

Peserta (lansia) yang mengikuti edukasi penanaman seledri 10 orang. Keluarga yang mendampingi dalam proses edukasi didominasi oleh anak/menantu. Pelaksanaan kegiatan sosialiasi tentang pemanfaatan seledri terhadap hipertensi dibuka pada pukul 09.00 WIB sampai dengan selesai yang dimulai dari kata sambutan oleh ketua panitia, kemudian penyampaian materi pemanfaatan seledri terhadap hipertensi.

Hasil dari kegiatan ini lansia mampu memahami tentang hipertensi mulai dari definisi, etiologi, manifestasi klinis, pemeriksaan diagnostik, pemeriksaan penunjang komplikasi, pencegahan dan penatalaksanaan untuk menurunkan tekanan darah penderita hipertensi dengan penatalaksanaan farmakologi maupun non farmakologi.

Tabel 1. Distribusi Frekuensi Lassia Berdasarkan Pengetahuan Tentang Seledri dan Hipertensi

\begin{tabular}{|l|l|l|l|l|l|}
\hline No & $\begin{array}{l}\text { Kategori } \\
\text { Pengetahuan }\end{array}$ & Pretest & Post test \\
\cline { 3 - 6 } & & Frekuensi & Persentase & Frekuensi & Persentase \\
\hline 1 & Baik & 0 & 0 & 6 & 60 \\
\hline 2 & Cukup & 2 & 20 & 3 & 30 \\
\hline 3 & Kurang & 8 & 80 & 1 & 10 \\
\hline & Total & 10 & 100 & 10 & 100 \\
\hline
\end{tabular}

Dari tabel diatas dapat dilihat bahwa ada peningkatan pengetahuan setelah dilakukan sosialisi tentang seledri dan hipertensi, dimana sebelum dilakukan sosialisasi mayoritas peserta berpengetahuan kurang sebesar 8 orang $(80 \%)$, setelah dilakukan sosialisasi mayoritas peserta berpengetahuan baik sebesar 6 orang $(60 \%)$.

\section{Kegiatan Demonstrasi}

Kegiatan demonstrasi pemanfaatan daun seledri dilaksanakan pada pukul 08.30 WIB s/d selesai oleh Tim Pengabdian bersama lansia dilaksanakan disalah satu rumah peserta. Kegiatan demonstrasi pemanfaatn daun seledri diikuti oleh 10 orang lansia, anggota posbindu dan tim pengabdian. Kegiatan ini membuat lansia mampu memahami dan menerapkan cara pembuatan rebusan daun seledri dengan baik dan benar sebagai salah satu terapi nonfarmakologis untuk pengontrolan tekanan darah. Selanjutnya dilakukan demonstrasi penanaman seledri oleh tim pengabdian.

\section{Kegiatan Pendampingan}

Kegiatan Pendampingan penanaman seledri dilaksanakan pada pukul 09.00 WIB sampai dengan selesai yang dilaksanakan oleh Tim Pengabdian Masyarakat langsung ke rumah-rumah peserta untuk dilakukan pendampingan cara penanaman seledri dipekarangan masing-masing.

\section{KESIMPULAN}

Kegiatan pengabdian masyarakat dilakukan dimulai dari sosialisasi, dimana dilakukan pretest dan post test, dimana ada peningkatan pengetahuan setelah dilakukan sosialisi tentang seledri dan hipertensi, dimana sebelum dilakukan sosialisasi mayoritas peserta berpengetahuan kurang sebesar 8 orang $(80 \%)$, setelah dilakukan sosialisasi mayoritas 
peserta berpengetahuan baik sebesar 6 orang (60\%). Peserta pengabdian yang menjadi sasaran tim pengabdian adalah sebanyak 10 peserta dimana setelah dilakukan sosialisasi selanjutnya dilakukan demonstrasi dan pendampingan langsung cara penanaman seledri dipekarangan.

\section{REFERENSI}

Djojoseputro, S. (2012). Seledri:Menjaga Kesehatan \& Kecantikan. Stomata.

Harmilah, dan, \& Ekwantini, R. D. (2014). JUS SELEDRI (APIUM GRAVEOLENS) MENURUNKAN TEKANAN DARAH TIKUS RATTUS STRAIN WISTAR DENGAN HIPERTENSI. JOURNAL OF HEALTH TECHNOLOGY, 5 nomor 1. http://eprints.poltekkesjogja.ac.id/id/eprint/599

James, P. A., Oparil, S., Carter, B. L., Cushman, W. C., Dennison-Himmelfarb, C., Handler, J., Lackland, D. T., LeFevre, M. L., MacKenzie, T. D., Ogedegbe, O., Smith, S. C. J., Svetkey, L. P., Taler, S. J., Townsend, R. R., Wright, J. T. J., Narva, A. S., \& Ortiz, E. (2014). 2014 evidence-based guideline for the management of high blood pressure in adults: report from the panel members appointed to the Eighth Joint National Committee (JNC 8). JAMA, 311(5), 507-520. https://doi.org/10.1001/jama.2013.284427

Kemenkes RI. (2018). Hasil Riset Kesehatan Dasar Tahun 2018. Kementrian Kesehatan RI, 53(9), 1689-1699.

Kemenkes RI. (2019). Hipertensi Si Pembunuh Senyap. Kementrian Kesehatan RI, 1-5. https://pusdatin.kemkes.go.id/resources/downl oad/pusdatin/infodatin/infodatin-hipertensi-sipembunuh-senyap.pdf

Khomsan, A. (2010). Pangan Dan Gizi Untuk Kesehatan. Raja Grafindo Persada.

Madhavi, D., Kagan, D., Rao, V., dan Murray., M. T. (2013). A Pilot Study to Evaluate the Antihypertensive Effect of a Celery Extract in Mild to Moderate Hypertensive Patients. Natural Medicine Journal, Vol. 5(Issue 4). https://www.naturalmedicinejournal.com/jour nal/2013-04/pilot-study-evaluate-

antihypertensive-effect-celery-extract-mild- moderate

Rahayu Sri. (2017). Sehat Tanpa obat Dengan Seledri. Rapha Publishing.

Sumatera Utara, D. K. (2019). Provinsi Sumatera Utara. Jurnal Ilmiah Smart, III(2), 68-80.

Wijaya, A. K. (2019). Pemanfaatan Daun Seledri Dipekarangan Rumah Untuk Pengontrolan Tekanan Darah Dan Membantu Perekonomian Keluarga. Jurnal Pengabdian Masyarakat Bumi Raflesia, 2(2), 138-147. https://doi.org/10.36085/jpmbr.v2i2.441 